\section{AGU Advocacy for Science}

PAGE 385

Congress needs input from the scientific community and reacts to responsible and informed advocacy. At the American Association for the Advancement of Science Colloquium on Research and Development in April 1989, Robert E. Grady, associate director for natural resources, energy and science at the Office of Management and Budget told the audience of scientists "I certainly hope that in all areas the scientific community will not remain silent ... You are being out-lobbied...." While there are now organized efforts within the scientific community to provide advice and information, the role of the individual is still important.

How does this affect the geosciences and AGU members? Topics such as global change, the Loma Prieta and other earthquake hazards and the current solar max period continue to make the headlines and to be vital topics of national and international concern. We must take the time to make congressional and administration contacts, to explain the underlying science of such topics and to advocate appropriate programs of research.
As a Union, we have been active. For example, we support a very successful Congressional Fellows Program; we address issues of the geosciences that affect the public at our meetings and invite policymakers to these (last December, congressional hearings on the Loma Prieta earthquake were held at the AGU Fall Meeting); at the request of the President's Science Advisor, AGU has reviewed the plans for the U.S. Global Change Research Program. Other activities, such as possible seminars on Capitol Hill are being considered. These activities are well received by national policymakers, and AGU's reputation as a source of sound advice is steadily building. Also, as a Union we have developed positions on important topics through a process that protects $\mathrm{A}$ (jU well from the risk of appearing to advocate overly narrrow or selfserving positions. The positions that have been adopted are in the broad interest of the geosciences and as members we should promote these positions as well as their individual views.

There is always the question of "What should individual scientists do:" Here are some suggestions:

Become familiar with the interests and committee assignments of your local representative, your senators and their staff. If they serve on committees with some overview of science or the general budget, so much the better. If not, they still will have important floor voices in science matters. Take opportunities, perhaps offered through your institutions or otherwise, to meet them to discuss science. Recognize that they are incredibly busy, but be prepared to contact them by letter or visit when a major scientific issue surfaces.

Pay close attention to critical points in the fast changing budget process. Issues of science funding and policy will be highlighted, as they emerge in Eos and other scientific newsletters. Be prepared to act quickly to raise the issue and to recommend specific actions to your congressional delegation and to the involved committees. AGU staff or COPA members can help you with specific suggestions and the AGU Legislative Guide is being updated and will be avaliable soon.

Become familiar with AGU positions on geoscience issues and make them part of your discussions and correspondence where appropriate. AGU positions on fencing and on hydrologic science were recently approved by Council and are published in this issue of Eos.

Decision makers in Congress and the Administration welcome informed advice and public interest in their actions. AGU, with its 25,000 members, should play a significant role in providing this advice on matters of the geosciences.

H. Frank Eden

Chairman, AGU Committee in Public Affairs

\title{
Continental Coring of the Newark Rift
}

PAGES 385, 394

\section{Paul E. Olsen and Dennis V. Kent}

Lamont-Doherty Geological Observatory, Palisades, New York

The entire Late Triassic record of the Newark continental rift of New Jersey, New York, and Pennsylvania will be drilled to recover about $7000 \mathrm{~m}$ of continuous core under the National Science Foundation's Continental Lithosphere Program. Unlike the relatively well-known postrift sedimentary succession of continental margins, there is hardly any continental rift sequence known in the detail necessary for quantitative tectonic or stratigraphic models. The Newark basin is one of the most accessible and most studied rifts in the world. While much has been learned over the 150 years of study by piecing together the record from discontinuous outcrops [Manspeizer, 1988; Olsen et al., 1989], inevitable

Cover. (Left) A real lightning and (right) its counterpart generated by computer using equations that describe chaotic dynam- uncertainties in correlation and facies relationships have hampered the development of a comprehensive tectonic and stratigraphic history.

The Newark basin (Figures 1,2) is one of a series of rifts that developed during the 60 m.y. $(235-175 \mathrm{Ma})$ prior to the production of the earliest oceanic crust in the region along the North American-African suture. In eastern North America, these rifts formed along reactivated Paleozoic thrust faults that follow the grain of the Appalachian orogen; the exposed fill of these rifts is termed the Newark Supergroup [Froelich and Robinson, 1988] (Figure 1).

The Newark basin in cross section is a rela-

ical systems and fractal structures. Photo courtesy of A. A. Tsonis and J. B. Elsner, University of Wisconsin-Milwaukee.

PAGE 400 tively simple, faulted, and partially folded half graben with a series of right-stepping relay boundary faults on its western edge (Figures 1,2); in longitudinal section the basin is a synform. All of the basin fill is continental in origin and most is lacustrine. The oldest sediments are probably early Late Triassic in age (early Carnian $230 \mathrm{Ma}$ ), and the youngest are Early Jurassic in age (Sinemurian 199 Ma). The overall stratigraphic architecture (Figure 3) in the Triassic age part of the Newark basin is very similar to many rift basins of the world, and consists of three parts: a basal fluvial sequence (Stockton Formation), a middle "deep water" lacustrine sequence (Lockatong Formation), and an upper "shallow water" sequence (Passaic Formation). It is just this sort of common stratigraphic pattern that needs to be quantitatively modeled and physically explained. The sedimentary section of Early Jurassic age is also mostly lacustrine but its lower part is interbedded with thick thoeliitic lava flows (Figures 1-3)

A critical characteristic of the 26-m.y.-long lacustrine section of the Lockatong and Passaic formations is that it is primarily composed of a hierarchy of sedimentary cycles caused by the rise and fall of lake level, first identified in the Newark basin by Franklyn Van Houten. These sedimentary rhythms have been interpreted as reflecting climate cycles controlled by Milankovitch-type forcing (Figures 3,4$)$. Characteristic periods of the precession of the equinoxes (presently 19,000 and 23,000 years), cycles of the obliquity of the Earth's axis (presently 4l,000 and 54,000 years), and cycles of the eccentricity of the 

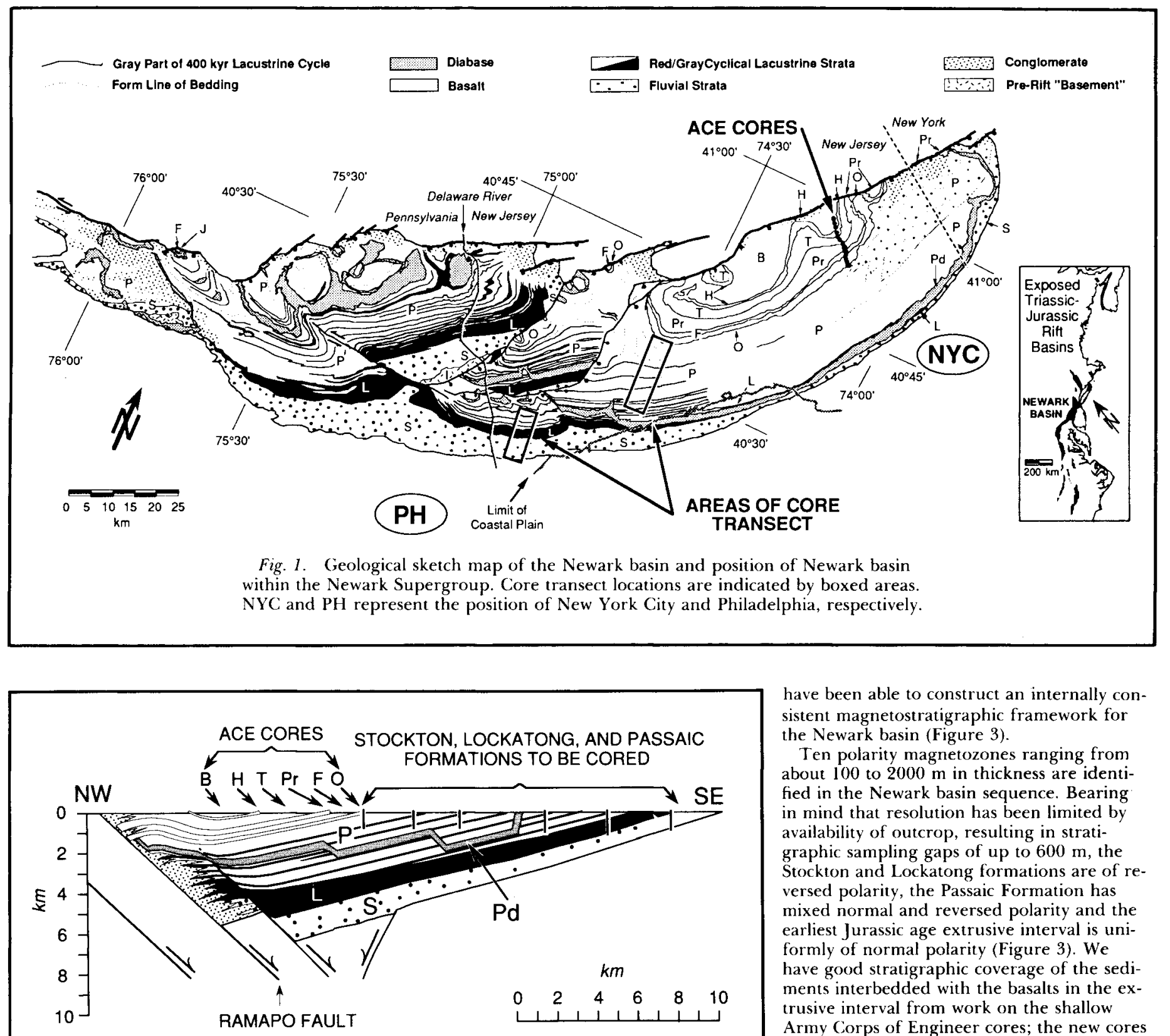

Fig. 2. Generalized cross section of Newark basin based on surface data in transect areas with position of core holes shown diagrammatically. Note that the Palisade Diabase (Pd) will be avoided in the core transect, and key lithostratigraphic marker beds (distinctive Van Houten cycles) will be used to correlate between holes. Symbols as for Figure 1.

Earth's orbit $(95,000,123,000,413,000$, and $2,035,000$ years) have been identified in outcrops of sections of the Lockatong and Passaic formations (Figure 4) [Olsen, 1986]. These cycles are present over the entire lacustrine section, but general lack of continuous outcrop precludes detailed analysis, a problem addressed by the proposed coring.

The geomagnetic polarity time-scale is well known from analysis of marine magnetic anomalies back to about the middle Jurassic, the age of the oldest ocean floor. Prior to that time, geomagnetic polarity history must be determined from magnetostratigraphic studies of land sections; prerequisites include availability of continuous and well-dated sec- tions with favorable magnetic properties. Paleomagnetic work in progress on outcrops and shallow cores in the Newark basin, in conjunction with the available cyclostratigraphy, demonstrate that the Newark Supergroup sediments satisfy these requirements [e.g., Witte and Kent, 1989]. Although the magnetizations are not simple and typically include a pervasive overprint related to a hydrothermal event in the late stages of basin development, a characteristic penecontemporaneous magnetization of normal and reversed polarity can be consistently isolated. Using distinctive Van Houten cycles as key lithostratigraphic marker beds to correlate between a half dozen sampling transects, we have been able to construct an internally consistent magnetostratigraphic framework for the Newark basin (Figure 3).

Ten polarity magnetozones ranging from about 100 to $2000 \mathrm{~m}$ in thickness are identified in the Newark basin sequence. Bearing in mind that resolution has been limited by availability of outcrop, resulting in stratigraphic sampling gaps of up to $600 \mathrm{~m}$, the Stockton and Lockatong formations are of reversed polarity, the Passaic Formation has mixed normal and reversed polarity and the earliest Jurassic age extrusive interval is uniformly of normal polarity (Figure 3). We have good stratigraphic coverage of the sediments interbedded with the basalts in the extrusive interval from work on the shallow

Army Corps of Engineer cores; the new cores will allow comparable stratigraphic resolution in the Triassic strata with no sampling gaps. The resulting polarity stratigraphic sequence will be calibrated in time using the Milankovitch cyclostratigraphy.

The principal objective of this project is the recovery, with continuous core, the entire approximately $6-\mathrm{km}$-thick Late Triassic age section spanning the stratigraphic interval from the base of the Early Jurassic age basalt flows to metamorphic Paleozoic and Precambrian basement in New Jersey (Figure 1). What will be gained from the coring is a high-resolution chronostratigraphy of the Newark rift basin, which will include production of a detailed Milankovitch-type cyclostratigraphy at the 20,000-year level of resolution based on sediment fabrics and optical characteristics of the core, documentation of the biostratigraphy (palynology) of the cored interval, and production of a detailed magnetostratigraphy of the core. This detailed record will allow most of exposed portions of the basin to be correlated at the same scale of resolution, provide a basis for developing and test- 


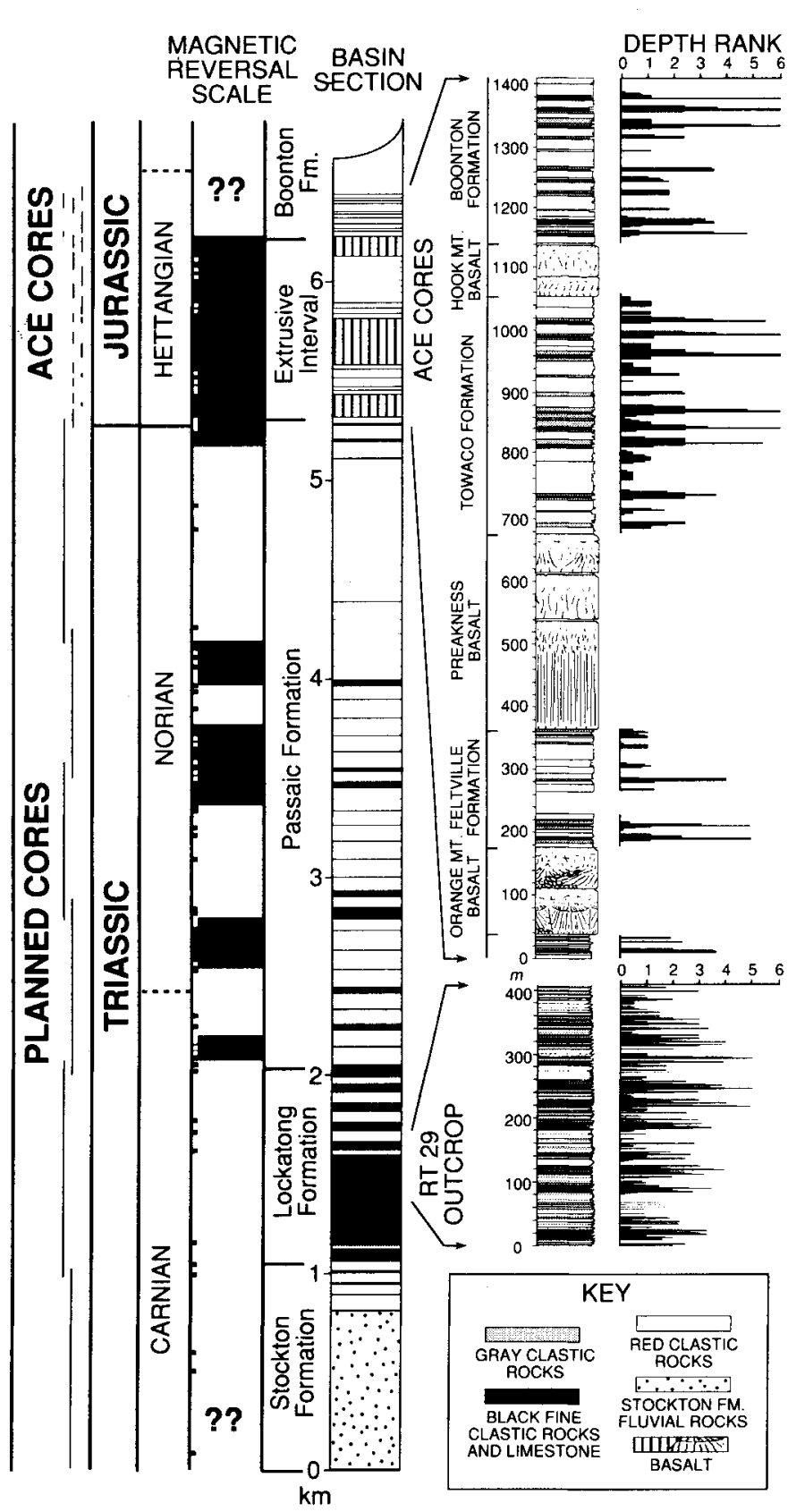

Fig. 3. Newark basin stratigraphy and magnetic reversal sequence showing details of cyclical lacustrine deposition based on cores from the Army Corps of Engineers (ACE) and surface outcrops. Depth rank is a proxy of lake depth based on sediment fabric that correlates with organic carbon content and fossil preservation (see Figure 4). Route 29 section described by Olsen [1986]. Black/open bars in the magnetic reversal scale represent normally/reversed magnetized zones and the ticks represent sampling sites of surface outcrops and the ACE cores, projected to common stratigraphic base using key lithostratigraphic marker beds.

ing quantitative models of rift basin evolution, and be the basis of a standard biostratigraphic, and geomagnetic reversal time scale for the Late Triassic.

The overall drilling plan is to commence coring in the lower part of the section in summer-fall 1990 and to complete coring by the end of 1991. To optimize competing cost and scientific considerations regarding depths of penetration, the gently dipping section will be cored in a series of 5-6 relatively shallow holes (nominally $1100 \mathrm{~m}$ ) along two transects trending north-south in central New Jersey (Figure 2). The rationale for two transects is to avoid the stratigraphic and alteration complications caused by the Palisade sill, which in our present plans will not be cored (Figure 1). The first transect will be to the east of the Delaware River in the southern fault block and will cover the stratigraphic interval from
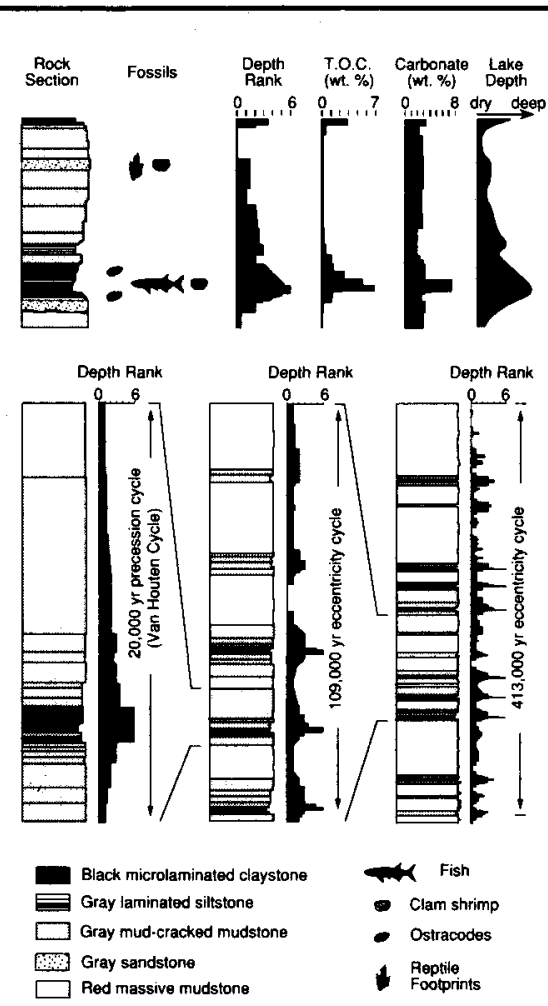

Fig. 4. Sedimentary cycles caused by Milankovitch-type climate changes. Top, single lake sequence (Van Houten cycle) showing changes in depth rank and associated variation in chemistry and fossil content. Bottom, compound cycles made up of increasing hierarchies of Van Houten cycles.

the base of the Stockton Formation to the Perkasie Member of the lower Passaic Formation in three cores. The second transect will be in the New Brunswick to Bound Brook area and will cover the stratigraphic interval from the Perkasie Member to the base of the Jurassic basalts (Figure 3 ) in three more cores. The correlation datum between the transects will be the lithologically distinctive Perkasie Member, which also is characterized by a geomagnetic polarity transition at its base.

Core diameter will be at least 2 inches (5 $\mathrm{cm}$ ) and anticipated hole diameter will accommodate slim-hole logging tools, including a borehore televiewer (to assure core orientation), as well as a variety of standard techniques including natural gamma radioactivity, neutron density, and resistivity. Core orientation will primarily be by televiewer orientation of bedding planes and fractures matched to the core. The core will be split longitudinally with one half intended for archiving and the other half for sampling. Initial core storage and handling will be at Lamont-Doherty Geological Observatory in Palisades, New York.

The Newark basin coring project should be viewed as an opportunity for additional scientific investigations, and we would be happy to provide information and guidance for requests for support for projects based on these core material, logs, as well as the holes. The cores and logs, of course, will be available in- 
definitely to the scientific community; however because of monetary and safety considerations, the holes themselves must either be sealed shortly after logging, or responsibility for their closure must be accepted by the interested party. A few obvious associated projects might include coring of the Palisade sill, organic-inorganic geochemistry, sedimentary petrology, and clay mineralogy of the cores and sedimentary cycles, geophysical logging tool calibration, installation of down-hole seismometers, production and analysis of seismic profiles along core hole transects, groundwater studies, and magnetic mineralogy.

An informal evening session is scheduled for May 29 at the Convention Center, 7:30-9 P.M., room 305, during the AGU Spring
Meeting in Baltimore, Md. Interested persons should contact Paul Olsen or Dennis Kent at 914-359-2900. A workshop on the core project was presented at the Northeast Section meeting of the Geological Society of America held May 5-7 in Syracuse, N.Y.

\section{References}

Froelich, A. J., and G. R. Robinson, Jr. (Eds.), Studies of the Early Mesozoic basins of the eastern United States, U.S. Geol. Surv. Bull. $1776,423,1988$

Manspeizer, W. (Ed.), Triassic-Jurassic Rifting. Continental Breakup and the Origin of the Atlantic Ocean and Passive Margins, Dev. Geotech., 22, 998 pp., Elsevier, Amsterdam, 1988.
Olsen, P. E., A 40-million-year lake record of early Mesozoic orbital climatic forcing, Science, 234, 842, 1986.

Olsen, P. E., R. W. Schlische, and P. J. W. Gore (Eds.), Field guide to the tectonic, depositional, and paleontological history of early Mesozoic rift basins, eastern North America, 28th International Geological Congress, Guidebooks for Field Trips, Guideb. T351, 174 pp., 1989.

Witte, W. K., and D. K. Kent, A Middle Carnian to early Norian (225 Ma) paleopole from sediments of the Newark Basin, Pennsylvania, Geol. Soc. Am. Bull., 101, $1118,1989$.

\section{News}

\section{Senate Passes Clean Air Bill}

PAGE 387

In an 89 to 11 vote the Senate passed a clean air bill aimed at reducing pollution by the turn of the century by imposing tougher controls on American industry. The bill is the first revision of the Clean Air Act of 1970 in 13 years and calls for new limits on auto pollution to clean up smog in most U.S. cities, decreasing by half emissions by power plants that cause acid rain to protect the ecology, and increasing technological controls on factories to protect against cancer-causing and toxic substances. The bill will add about $\$ 20$ billion per year to the estimated $\$ 33$ billion cost of complying with current pollution laws.

To reduce acid deposition, the bill would require coal-fired power plants to reduce sulfur dioxide emissions, precursors to acid rain, by 10 million tons by the beginning of the next century. The bill would also establish a national ceiling on sulfur emissions to be maintained at that established level, and a 2-million-ton reduction in nitrogen oxide emissions. According to Paul R. Portnoy, vice president of Resources for the Future, bene fits of proposals concerning acid rain, including less damage to forests, less ecological damage and increased visibility in metropolitan areas, exceed the compliance cost of about $\$ 4-5$ million.

The new bill is aimed at the more than 100 major cities that still do not comply with requirements of the original Clean Air Act on urban smog levels. Cities would be required to make annual reductions in smog levels. Legislation would focus new controls on pollution from motor vehicles, the single largest source of smog.

The Senate bill would regulate toxic chemicals that pose a threat to public health, re quiring all major sources of pollution of about 200 chemicals to install control technology to reduce pollution. Additional measures may be necessary if a high health risk still exists after these controls are implemented.

Industry and environmentalists are both unhappy with elements of the Senate compromise; industry contends that costs of compliance are still too high and will result in lost businesses and jobs. Environmentalists argue that the new bill is not adequate to protect public health and the environment, although it has provisions that apply to many of the goals they seek, such as reducing pollution that leads to acid rain.

The Energy and Commerce Committee in the House is currently writing a bill that would be more stringent than the Senate version. A vote could be taken later this month or in May. $-S M B$

\section{Atmospheric Model Assessment}

\section{PAGE 387}

The American Institute of Aeronautics and Astronautics has recently released Guide to Reference and Standards Atmospheric Models, an in-depth assessment of atmospheric models, describing the chemical composition and physical properties of the atmosphere. Models range from the Earth's surface to 2500 $\mathrm{km}$ and include model description, development rationale, uncertainties, limitations, origins, and computer code availability. For a copy, contact AIAA, Standards Department, 370 L'Enfant Promenade, S.W., Washington, DC 20024

\section{Polarimetric Radar Modified}

\section{PAGE 387}

Modification of $11-\mathrm{cm}$ Doppler radar, to permit measurement of the complete polari- metric matrix of signals backscattered from meteorological media, was recently completed by the Ground Based Remote Sensing Branch of the Geophysics Laboratory, U.S Air Force Base, Hanscom, Mass. It is believed that this radar is the only meteorological research radar in the world having such a capability at this wavelength. Signals can be transmitted with either linear or circular polarization and switched pulse-to-pulse either between horizontal and vertical or between right and left circular polarization.

Backscattered signals with polarizations identical and orthogonal to that of the transmitted signal pass through coherent and logarithmic receivers and are recorded as time series in 40 selectable range gates. The resulting data archive supports a wide range of analyses, including auto- and cross-covariance calculations and spectral analyses.

The absolute reflectivity $Z$, Doppler mean velocity, and differential reflectivity $\left(Z_{D R}\right.$, in the linear polarization mode) are computed, displayed, and recorded in real time to aid the acquisition and analysis of the full-matrix data and to support other research programs. Initially, the laboratory is using the polarimetric radar for investigations of cloud electrification. Other potential research uses include cloud microphysics, precipitation measurement, and signal propagation phenomenology.

The Geophysics Laboratory supports or participates in several programs for students and visiting scientists. These encompass summer employment for undergraduate and postgraduate students, 12-month postdoctoral appointments, summer appointments for academic faculty, and year-long visits by experienced scientists. U.S. citizenship is required for some, but not all, of these programs. For more information about the radar, the research program, opportunities for visiting scientists, or for other types of collaboration with the meteorological radar program, contact Kenneth Glover or James Metcalf, GL LYR, Hanscom Air Force Base, MA 01731; tel. 617-377-4405; fax 617-377-4498. 